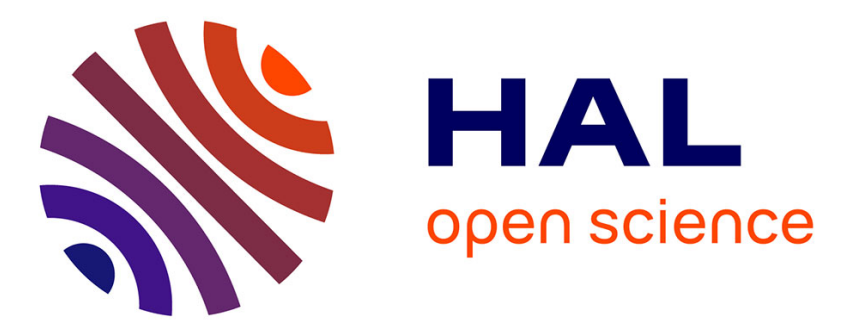

\title{
Study of the influence of the mastic coating of untreated reclaimed asphalt pavement on the permanent and resilient behavior
}

Laura Gaillard, Cyrille Chazallon, P. Hornych, Juan-Carlos

Quezada-Guajardo, Jean-Luc Geffard

\section{To cite this version:}

Laura Gaillard, Cyrille Chazallon, P. Hornych, Juan-Carlos Quezada-Guajardo, Jean-Luc Geffard. Study of the influence of the mastic coating of untreated reclaimed asphalt pavement on the permanent and resilient behavior. Journal of Testing and Evaluation, 2021, 10.1520/JTE20210200 . hal-03321040

\section{HAL Id: hal-03321040 \\ https://hal.science/hal-03321040}

Submitted on 16 Aug 2021

HAL is a multi-disciplinary open access archive for the deposit and dissemination of scientific research documents, whether they are published or not. The documents may come from teaching and research institutions in France or abroad, or from public or private research centers.
L'archive ouverte pluridisciplinaire HAL, est destinée au dépôt et à la diffusion de documents scientifiques de niveau recherche, publiés ou non, émanant des établissements d'enseignement et de recherche français ou étrangers, des laboratoires publics ou privés. 


\section{A J Journal of Testing and Evaluation}

\section{Study of the influence of the mastic coating of untreated reclaimed asphalt pavement on the permanent and resilient behavior}

\begin{tabular}{|r|l|}
\hline Journal: & Journal of Testing and Evaluation \\
\hline Manuscript ID & JTE-2021-0200 \\
\hline Manuscript Type: & Technical Manuscript \\
\hline Date Submitted by the & 25-Mar-2021 \\
\hline Complete List of Authors: & $\begin{array}{l}\text { Gaillard, Laura; INSA Strasbourg, Strasbourg University; ICube } \\
\text { Chazallon, Cyrille; INSA Strasbourg, Strasbourg University; ICube } \\
\text { Hornych, Pierre; Université Gustave Eiffel - Campus de Nantes, IFSTTAR } \\
\text { - MAST/LAMES } \\
\text { Quezada, Juan-Carlos; INSA Strasbourg, Strasbourg University; ICube } \\
\text { Geffard, Jean-LuC; Université Gustave Eiffel - Campus de Nantes, } \\
\text { IFSTTAR - MAST/LAMES }\end{array}$ \\
\hline KSTM Committees and & $\begin{array}{l}\text { D04.20 Mechanical Tests of Bituminous Mixtures < D04 ommittee on } \\
\text { Road and Paving Materials }\end{array}$ \\
\hline Kubcommittees: & $\begin{array}{l}\text { reclaimed asphalt pavement, mastic coating, repeated load triaxial test, } \\
\text { mechanical behavior }\end{array}$ \\
\hline &
\end{tabular}

\section{SCHOLARONE ${ }^{m}$ Manuscripts}




\title{
Study of the influence of the mastic coating of untreated reclaimed
}

\section{asphalt pavement on the permanent and resilient behavior}

\author{
Laura Gaillard ${ }^{1}$, Cyrille Chazallon ${ }^{2}$, Pierre Hornych ${ }^{3}$, Juan Carlos Quezada ${ }^{4}$, and Jean-Luc \\ Geffard $^{5}$
}

\begin{abstract}
Asphalt aggregates arise from the demolition of asphalt road layers. The ORRAP (Optimal Recycling of Reclaimed Asphalts in low-traffic Pavements) Project concerns the cold recycling of 100\% Reclaimed Asphalt Pavement (RAP) without binder addition in base and subbase layers of low-traffic roads. In this context, a test program was performed with Rhine Region materials to evaluate the impact of the mastic coating of untreated RAP. A source of reclaimed asphalts with $4.4 \%$ of bitumen is tested before (RAP) and after binder extraction (RAP-BE), then is compared to an unbound granular material (UGM) with a similar particle size distribution. Repeated Load Triaxial (RLT) tests were conducted at several frequencies to study the permanent and resilient behaviors. The results show that the RAP before binder extraction and the UGM present similar permanent behaviors, while the aggregates without binder reveal low strains. Concerning the resilient phase, the RAP and the RAP-BE show similar levels of strains, but the resilient moduli

\footnotetext{
${ }^{1}$ ICUBE, INSA Strasbourg, Strasbourg University, Strasbourg, 67084, France; https://orcid.org/0000-0003-34478646

${ }^{2}$ ICUBE, INSA Strasbourg, Strasbourg University, Strasbourg, 67084, France; https://orcid.org/0000-0002-09935019

${ }^{3}$ MAST-LAMES, Gustave Eiffel University, IFSTTAR, Bouguenais, 44344, France; https://orcid.org/0000-00028733-9095

${ }^{4}$ ICUBE, INSA Strasbourg, Strasbourg University, Strasbourg, 67084, France; https://orcid.org/0000-0001-61647949

${ }^{5}$ MAST-LAMES, Gustave Eiffel University, IFSTTAR, Bouguenais, 44344, France

Page 1 of 26
} 
of the UGM are significantly lower than those of the RAP. From the experimental results, the nonlinear elastic Boyce model was fitted and brings out a highly anisotropic mechanical behavior of the RAP. Finally, the RAP shows a frequency sensitive viscous behavior due to the bitumen in the mastic, while the effect of frequency is negligible for the RAP-BE.

\section{Keywords}

reclaimed asphalt pavement, mastic coating, repeated load triaxial test, mechanical behavior.

\section{Introduction}

Many studies on recycling of asphalt aggregates have been carried out, in particular on the incorporation of Reclaimed Asphalt Pavement (RAP) in hot asphalt mixtures ${ }^{1-4}$, in warm processes by means of additives or foamed asphalts ${ }^{5-7}$, as well as in cold recycling with foamed or emulsion bitumen $^{8-10}$. However, the use of RAP without any addition, developed in Sweden ${ }^{11}$, is still not widespread. In France, the cold recycling strategy allows to reuse RAP with high Polycyclic Aromatic Hydrocarbons (PAH) contents (from $50 \mathrm{mg} / \mathrm{kg}$ to $500 \mathrm{mg} / \mathrm{kg}$ ). The ORRAP (Optimal Recycling of Reclaimed Asphalts in low-traffic Pavements) project concerns the cold recycling of $100 \%$ RAP without binder addition in base and subbase layers of low-traffic roads, instead of Unbound Granular Materials (UGM). In this framework, the effect of the mastic coating is studied, to measure the benefit of this recycling. A series of Repeated Load Triaxial (RLT) Tests is carried out at several frequencies to analyze the permanent strains and the resilient moduli of a source of untreated RAP with a PAH content of $298 \mathrm{mg} / \mathrm{kg}$ and to compare them with a conventional UGM. Then, the Boyce model is used to describe the resilient behavior of each material and to determine the resilient and characteristic moduli.

Page 2 of 26 


\section{Materials and Methods}

\section{Material characterization}

The tested RAP (fig. 1) comes from demolition of wearing courses of the Rhine Region. This material is defined as 25 RAP 0/14, according to the French Standard NF EN 13108-8 ${ }^{12}$, where 25 is the maximum size of particles before binder extraction and $0 / 14$ the grading of particles after binder extraction. The RAP contains $4.4 \%$ of grade $10 / 20$ bitumen. This material is studied before (RAP) and after binder extraction (RAP-BE), and then compared to an unbound granular material (UGM) with a similar particle size distribution (fig. 3). The UGM comes from the Rhine alluvium with a silico-calcareous mineralogical nature. This material was obtained from a composition of different particle size fractions (fig 2). Table 1 gives the main characteristics of the RAP and UGM. Unbound granular materials and asphalt mixtures represent the limits of the RAP behavior. Figure 3 shows the $0 / 14 \mathrm{~mm}$ UGM and the $0 / 14 \mathrm{~mm}$ asphalt mix grading curves and the corresponding limits of the French Standards ${ }^{13,14}$. The binder extraction produces fines, and consequently the fines content (passing through the $63 \mu \mathrm{m}$ sieve) is multiplied by four after extraction.

\section{FIGURE 1}

Reclaimed Asphalt Pavement from the Rhine Region

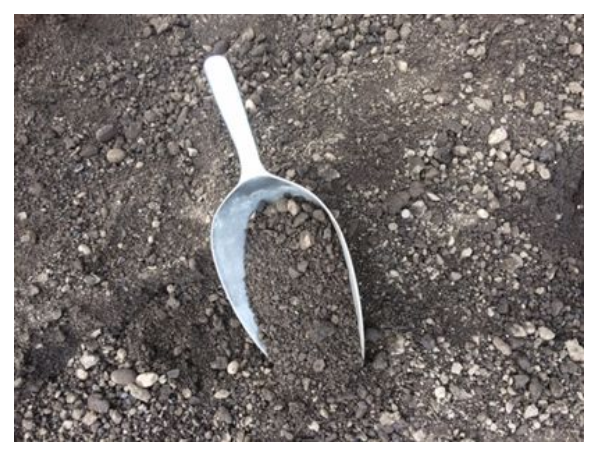

Page 3 of 26 


\section{FIGURE 2}

Size fractions for the composition of the UGM: (A) 0/4 mm (B) 4/6 mm (C) 6/10 mm (D) 10/14

$\mathrm{mm}$

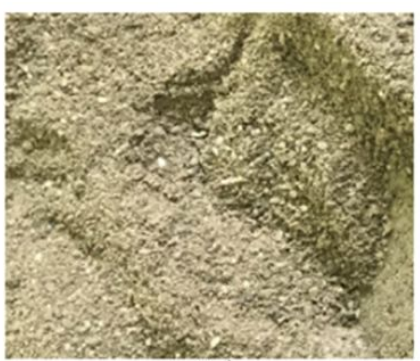

(A)

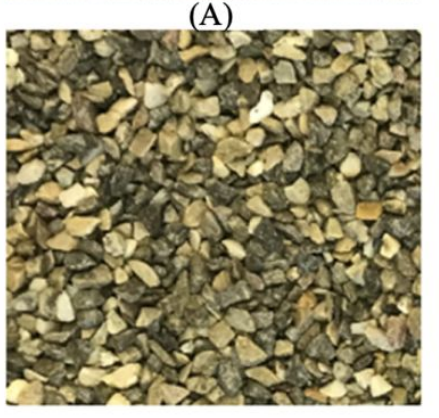

(C)

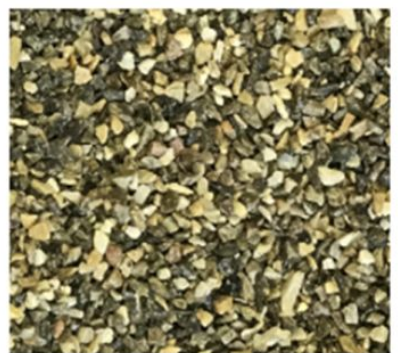

(B)

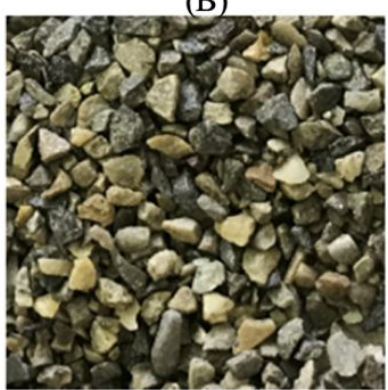

(D)

\section{FIGURE 3}

Particle size distributions of the studied materials
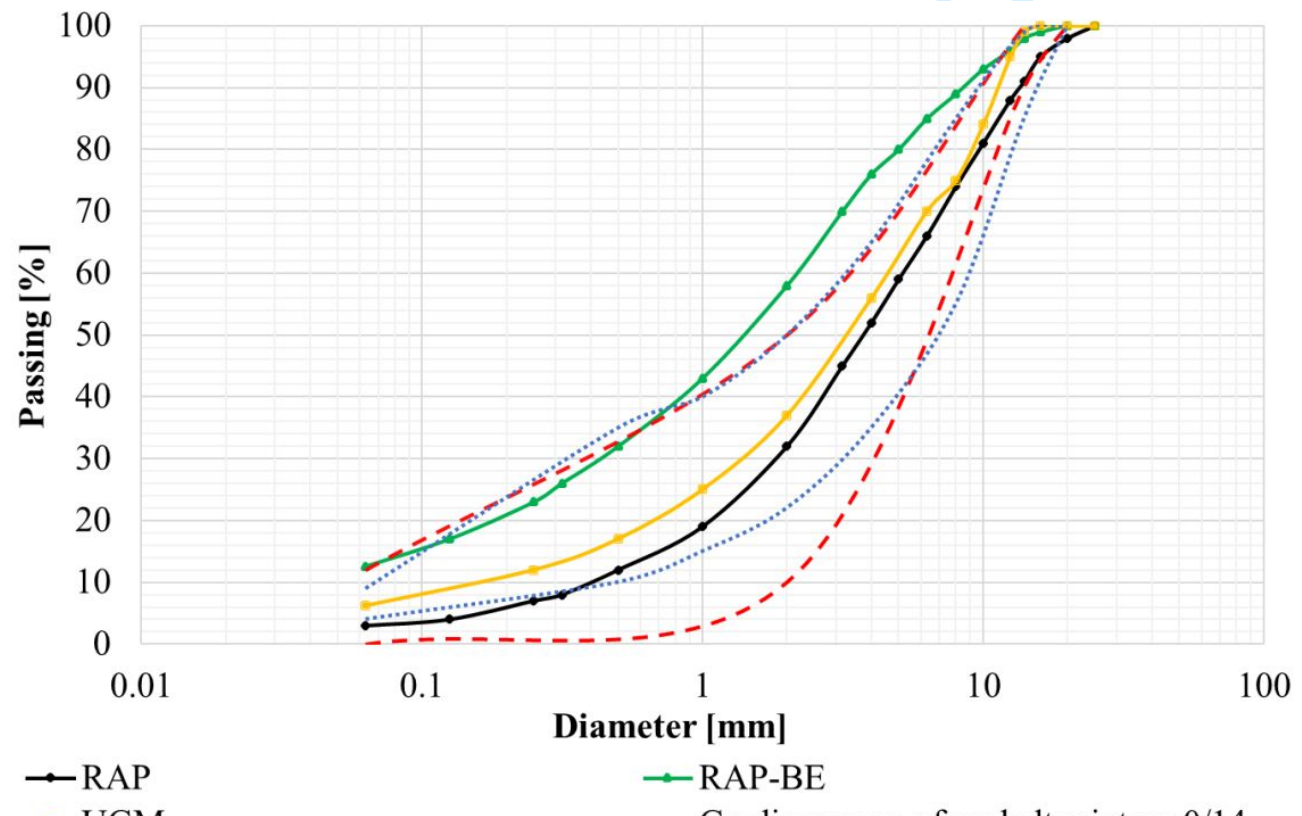

$\rightarrow$ RAP-BE

$=\mathrm{UGM}$

- - Grading range of asphalt mixture 0/14

....... Grading range of UGM 0/14

Page 4 of 26 
TABLE 1

Characteristics of the RAP and the UGM

\begin{tabular}{llll}
\hline & RAP & RAP-BE & UGM \\
\hline Grading, mm & $25 \mathrm{AE} 0 / 14$ & $0 / 14$ & $0 / 14$ \\
Particle density, g/cm3 & 2.48 & 2.65 & 2.64 \\
Proctor maximum dry density, g/cm3 & 2.02 & 2.21 & 2.16 \\
Proctor optimum water content, $\%$ & 5.86 & 5.31 & 7.60 \\
Binder content, \% & 4,4 & 0 & 0 \\
PAH content, $\mathrm{mg} / \mathrm{kg}$ & 298 & 0 & 0 \\
\hline
\end{tabular}

\section{Sampling}

The specimens are compacted using a vibrocompression device in one layer, by applying simultaneously a vertical load and a horizontal vibration. This method guarantees a homogeneous density within the sample. The cylindrical sample has a diameter of $160 \mathrm{~mm}$ and a height of 320 $\mathrm{mm}$. Table 2 presents the characteristics of different specimens.

\section{TABLE 2}

Characteristics of the specimens

\begin{tabular}{llll}
\hline & RAP & RAP-BE & UGM \\
\hline Compaction density, g/cm3 & 1.96 & 2.14 & 1.96 \\
Void content & 0.27 & 0.24 & 0.35 \\
Porosity, \% & 21.1 & 19.29 & 25.85 \\
Water content, \% & 3.9 & 3.3 & 3.9 \\
Number of specimens & 3 & 2 & 2 \\
\hline
\end{tabular}

\section{Triaxial apparatus}

The sample is placed in a triaxial cell, and a constant or variable cell pressure is applied using water as confining fluid and a servo-pneumatic system. A hydraulic actuator is used to apply the cyclic axial load. The specimen is instrumented with three Hall effect displacement transducers: 
two axial and one radial. Figure 4 presents the experimental device. Our system can apply a frequency of $10 \mathrm{~Hz}$ with constant cell pressure and $2 \mathrm{~Hz}$ with variable cell pressure. All the tests are performed at laboratory temperature $\left(20^{\circ} \mathrm{C}\right)$ and using the same test procedures as for unbound granular materials.

\section{FIGURE 4}

Experimental device: (A) instrumented specimen (B) triaxial cell on the hydraulic press

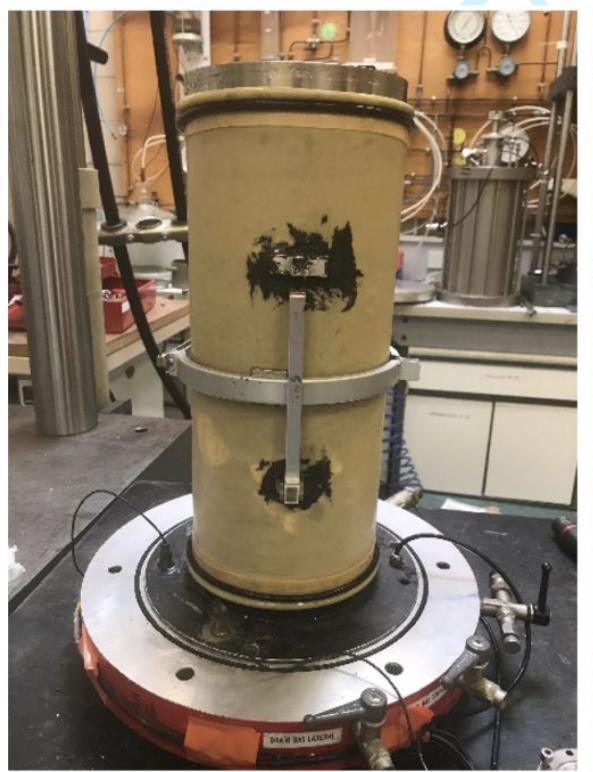

(A)

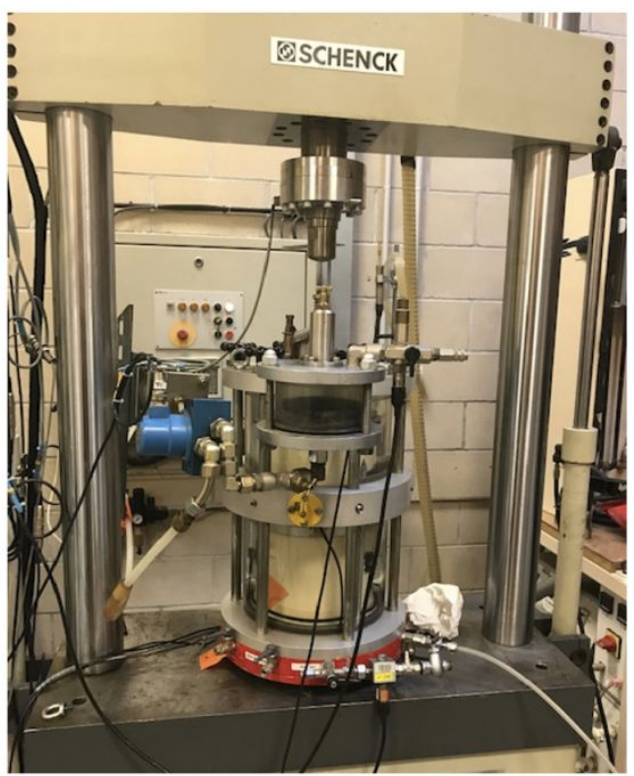

(B)

\section{Repeated Load Triaxial (RLT) tests}

The sign conventions are:

- $\quad$ The stresses are positive in compression.

- The axial and radial strains are positive in contraction.

- $\quad$ A positive (negative) volumetric strain indicates a contractant (dilatant) behavior.

The RLT test is one of the most reliable test methods to analyze the permanent and resilient 
behavior of unbound granular materials. The test method used in this work, defined by the French Standard EN 13286-715, allows to simulate traffic loads. The test principle (fig. 5) consists in applying a cyclic axial stress $\sigma_{1}$ and a constant or variable confining pressure $\sigma_{3}$. Equations (1) and (2) define the deviator stress $q$ and the mean stress p. During the test, the axial strains $\varepsilon_{1}$ and the radial strains $\varepsilon_{3}$ are measured, then the deviatoric strains $\varepsilon_{\mathrm{q}}$ and the volumetric strains $\varepsilon_{\mathrm{v}}$ can be calculated (equations (3)-(4)).

$$
\begin{gathered}
q=\sigma_{1}-\sigma_{3} \#(1) \\
p=\frac{\sigma_{1}+2 \sigma_{3}}{3} \#(2) \\
\varepsilon_{q}=2 \frac{\varepsilon_{1}-\varepsilon_{3}}{3} \#(3) \\
\varepsilon_{v}=\varepsilon_{1}+2 \varepsilon_{3} \#(4)
\end{gathered}
$$

The test presents two phases:

- The conditioning phase: application of a high stress level $\left(\Delta \mathrm{q}=340 \mathrm{kPa}, \Delta \mathrm{p}=113 \mathrm{kPa}, \sigma_{3}=70\right.$ $\mathrm{kPa}$ ) during 30,000 cycles at $2 \mathrm{~Hz}$ to stabilize the permanent strains.

- The resilient test: application of several stress paths, each during 100 cycles, to study the elastic strains at different frequencies (table 3). Figures 6 and 7 present the different stress paths with constant cell pressure $(\Delta \mathrm{q} / \Delta \mathrm{p}=3)$ and variable cell pressure $(\Delta \mathrm{q} / \Delta \mathrm{p} \neq 3)$. The unbound granular material (UGM) is tested at a constant frequency of $2 \mathrm{~Hz}$. 


\section{FIGURE 5}

Principle of the repeated load triaxial test ${ }^{16}$
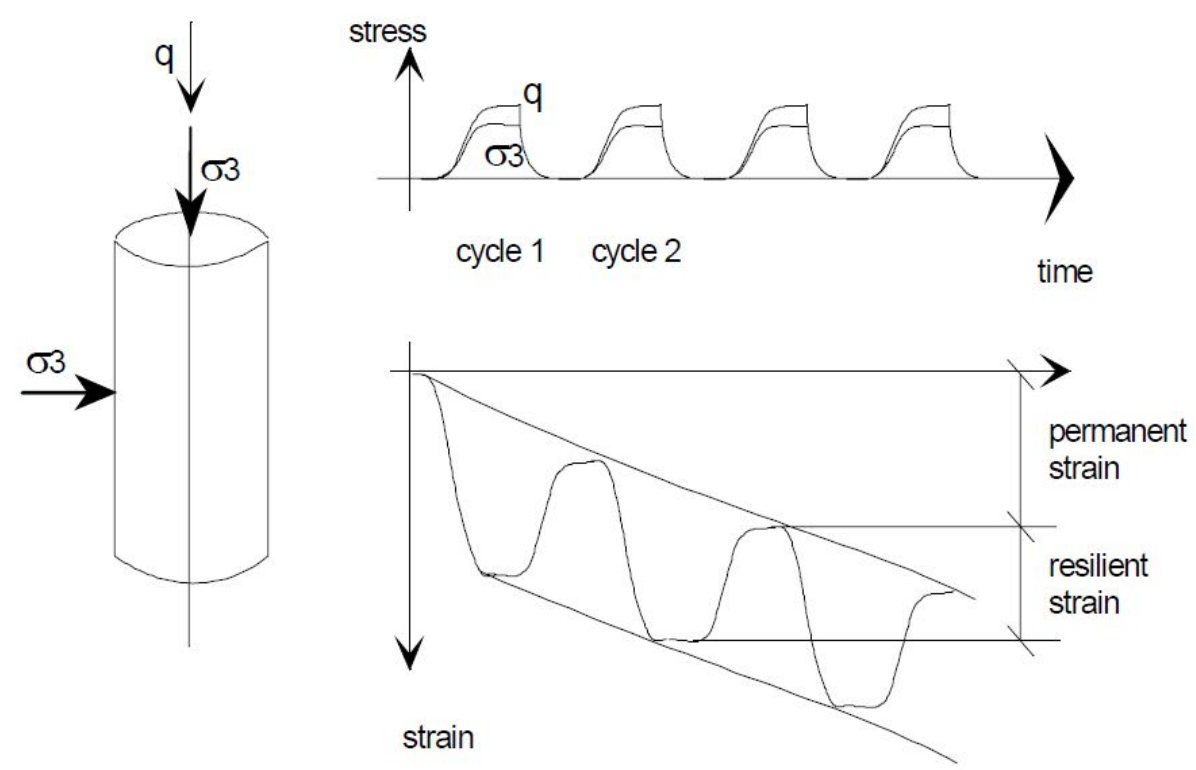

\section{TABLE 3}

Frequencies for the repeated load triaxial tests

\begin{tabular}{ll}
\hline Slope of stress path $\Delta \mathrm{q} / \Delta \mathrm{p}$ & Frequency, $\mathrm{Hz}$ \\
\hline $0,1,1.5,2$ & $0.1,0.5,1,2$ \\
3 & $0.1,0.5,1,2,5,10$ \\
\hline
\end{tabular}

Page 8 of 26 


\section{FIGURE 6}

Stress paths with constant cell pressure

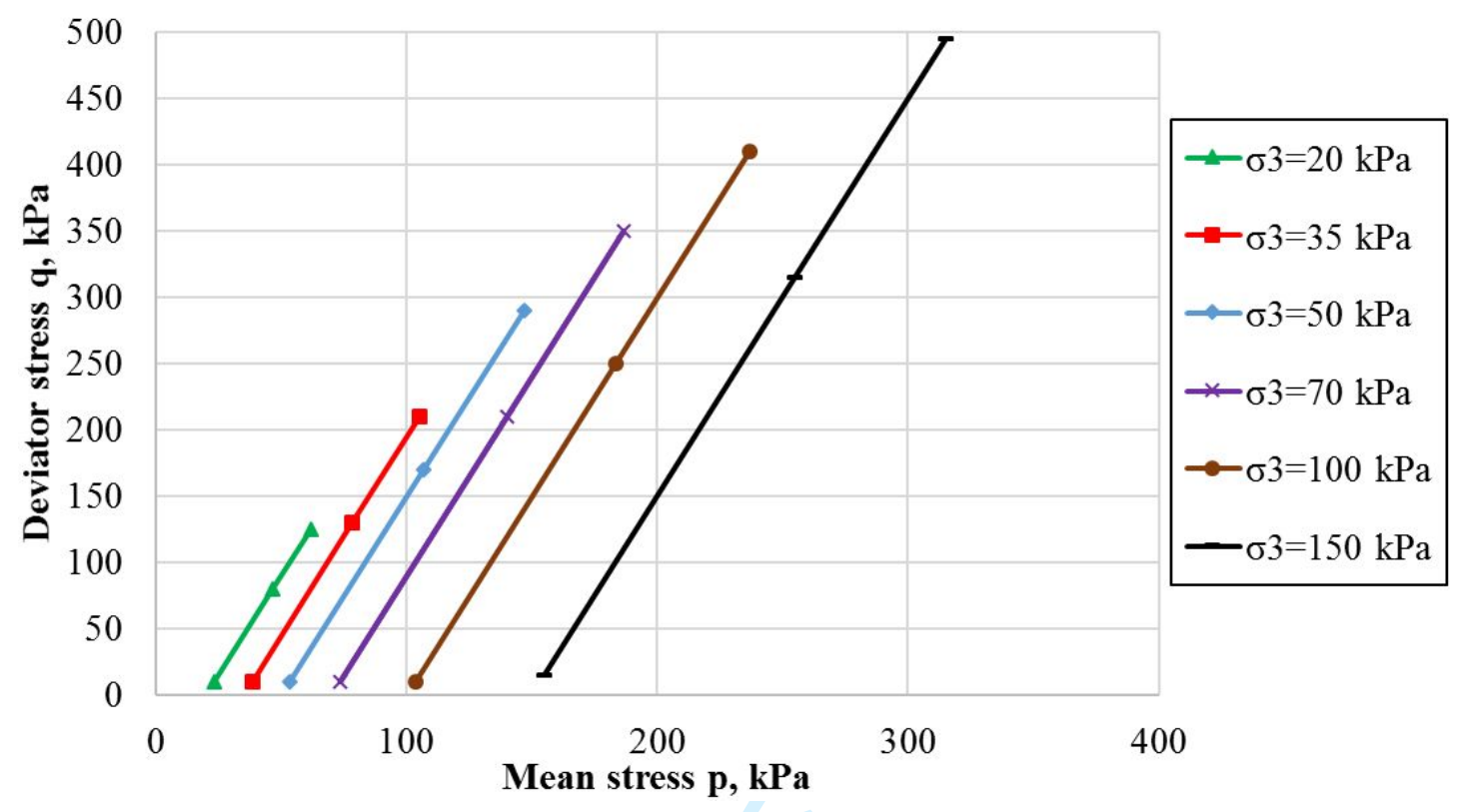

FIGURE 7

Stress paths with variable cell pressure

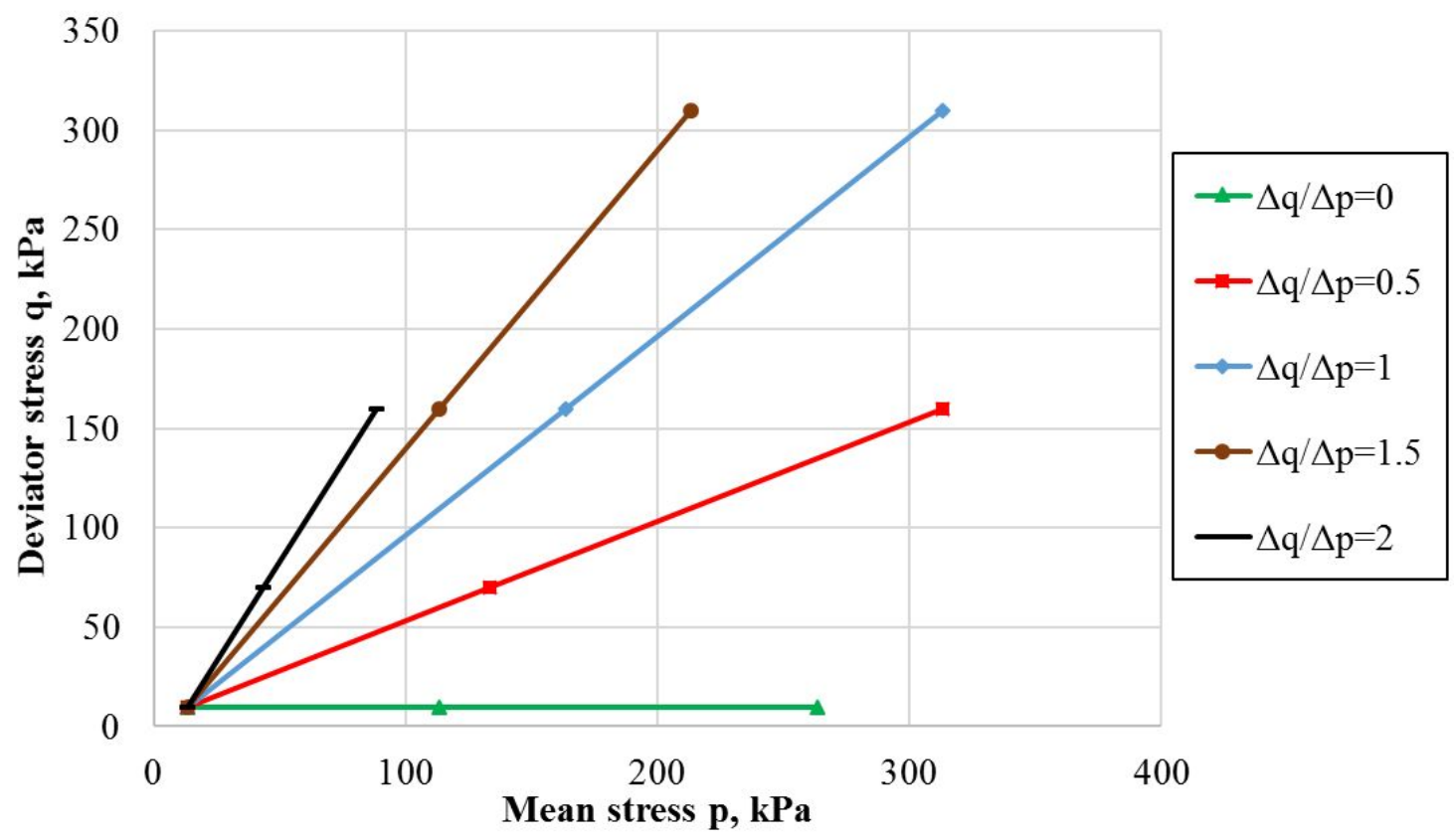

Page 9 of 26 


\section{Results and discussion}

\section{Conditioning phase}

Figures 8 and 9 show the evolution of the axial and radial permanent strains. The RAP before binder extraction and the UGM present similar permanent strains, particularly for the axial strains. However, the permanent strains of RAP-BE, after binder extraction, are much lower. These results can mainly be explained by the differences in fines content, in addition to the tested density and water content. The RAP before and after extraction present respectively $3.0 \%$ and $12.6 \%$ of fines. According to Jing, Nowamooz and Chazallon ${ }^{17,18}$, the quantity of fines improves the rutting resistance, until a critical water content close to saturation. Indeed, before binder extraction, the fines are trapped in the mastic coating, while after the extraction the fines are released and lead to a reduction of the rutting.

According to the French Standard for Unbound Granular Materials (UGM) NF EN 13286$7^{15}$, the axial permanent strains of the RAP are high and outside the specifications for use in base and subbase layers of low traffic pavements. However, the RAP presents a rutting resistance similar to the tested UGM. In order to reduce the rutting, the in situ density can be increased.

Page 10 of 26 


\section{FIGURE 8}

Evolution of permanent axial strains

(with an indication of standard deviations at cycles 10,000 and 30,000)

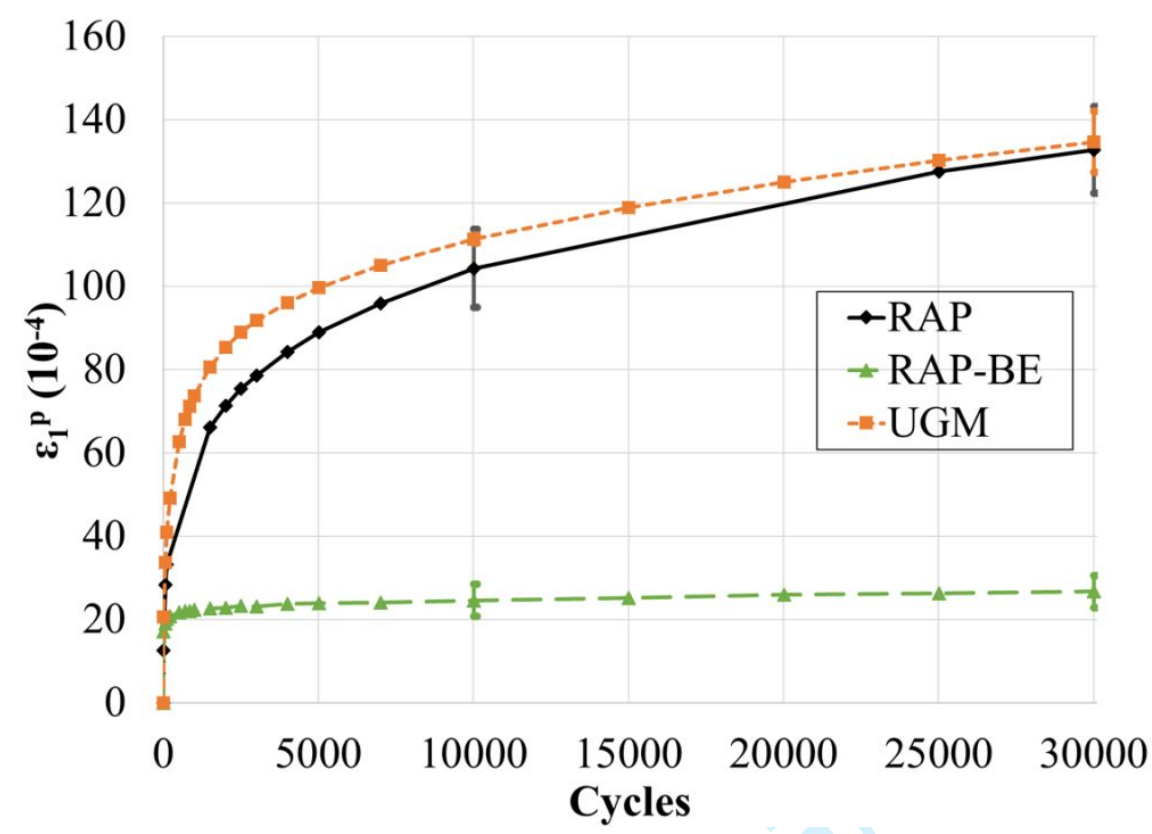

FIGURE 9

Evolution of permanent radial strains

(with an indication of standard deviations at cycles 10,000 and 30,000)

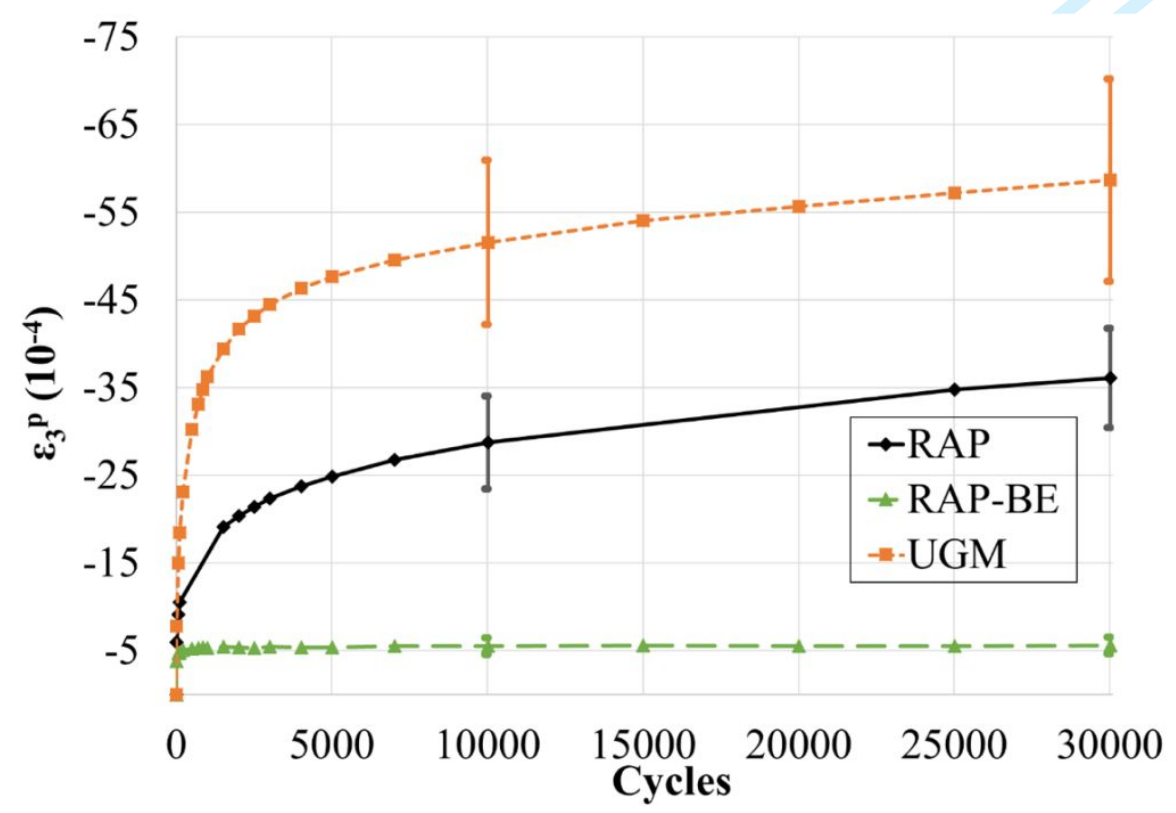

Page 11 of 26 


\section{Resilient test}

The resilient axial and radial strains are determined during the unloading phase of a cycle, using equations (5) and (6).

$$
\begin{aligned}
& \varepsilon_{1}^{r}=\varepsilon_{1}^{\max }-\varepsilon_{1}^{\text {min }} \#(5) \\
& \varepsilon_{3}^{r}=\varepsilon_{3}^{\max }-\varepsilon_{3}^{\text {min }} \#(6)
\end{aligned}
$$

The resilient strains allow to calculate the resilient modulus, using equation (7) for constant confining pressure or equation (8) for variable confining pressure.

$$
\begin{gathered}
E_{r}=\frac{\sigma_{1}^{r}}{\varepsilon_{1}^{r}} \#(7) \\
E_{r}=\frac{\sigma_{1}^{r^{2}}+\sigma_{1}^{r} \sigma_{3}^{r}-2 \sigma_{3}^{r^{2}}}{\sigma_{1}^{r} \varepsilon_{1}^{r}+\sigma_{3}^{r} \varepsilon_{1}^{r}-2 \sigma_{3}^{r} \varepsilon_{3}^{r}} \#(8)
\end{gathered}
$$

Boyce model

The non-linear elastic Boyce model ${ }^{19}$ effectively describes the resilient behavior of granular materials. Three parameters define this model: $n, K_{a}$ related to the bulk modulus and $\mathrm{G}_{\mathrm{a}}$ related to the shear modulus. Hornych, Kazai and $\mathrm{Piau}^{20}$ introduced the additional parameter $\gamma$ to take into account anisotropy of modulus. Consequently, equations (9)-(12) specify the model stresses and strains.

$$
\begin{gathered}
q^{*}=\gamma \sigma_{1}-\sigma_{3}, 0<\gamma<1 \#(9) \\
p^{*}=\frac{\gamma \sigma_{1}+2 \sigma_{3}}{3} \#(10)
\end{gathered}
$$

Page 12 of 26 


$$
\begin{gathered}
\varepsilon_{v}=\frac{\mathrm{p}^{* \mathrm{n}}}{p_{a}^{n-1}}\left[\frac{\gamma+2}{3 K_{a}}+\frac{n-1}{18 G_{a}}(\gamma+2)\left(\frac{q^{*}}{p^{*}}\right)^{2}+\frac{\gamma-1}{3 G_{a}} \cdot \frac{q^{*}}{p^{*}} \#(11)\right. \\
\varepsilon_{q}=\frac{2}{3} \cdot \frac{\mathrm{p}^{* \mathrm{n}}}{p_{a}^{n-1}}\left[\frac{\gamma-1}{3 K_{a}}+\frac{n-1}{18 G_{a}}(\gamma-1)\left(\frac{q^{*}}{p^{*}}\right)^{2}+\frac{2 \gamma+1}{6 G_{a}} \cdot \frac{q^{*}}{p^{*}}\right] \#(12)
\end{gathered}
$$

Where:

$\mathrm{p}_{\mathrm{a}}=$ atmospheric pressure, $100 \mathrm{kPa}$

The model parameters are calibrated using all experimental results and optimized using the least squares method.

\section{Comparison with the UGM}

Figures 10 and 11 present the results for the constant and variable cell pressure loadings respectively. Whatever the loading, the resilient behavior of the RAP and of the RAP-BE are similar, while the UGM presents higher strains and consequently lower resilient moduli.

At constant cell pressure, the behaviors of the RAP-BE and of the UGM are respectively contractant and dilatant, while the volumetric strains of the RAP are very small and depend on the confining pressure. For all three materials, the resilient modulus increases when the confining pressure increases. At variable confining pressure, the behavior of all three materials is purely contractant.

We notice that the UGM presents high strains, while the RAP specimens before and after binder extraction present similar levels of strains. Finally, if we consider RAP as an unbound Page 13 of 26 
granular material, the resilient moduli of RAP are high and indicate a good performance. These values are significantly higher than those of the Rhine Region UGM.

For the pavement design, the French Standard for UGM NF EN 13286-7 15 defines the characteristic elastic vertical modulus $E_{c}$ corresponding to the stress path: $q_{\max }=500 \mathrm{kPa}$ and $p_{\max }$ $=250 \mathrm{kPa}$. For the sake of precision, $\mathrm{E}_{\mathrm{c}}$ is determined from the calibration of the Boyce model.

For each material and frequency, the anisotropic Boyce model was fitted using all experimental results. Table 4 summarizes the model parameters for the calibrations at $2 \mathrm{~Hz}$. The last parameter $\mathrm{c}$ is the correlation coefficient varying between 0 and 1.

As expected, the UGM has a slightly higher correlation value. However, the model, developed for granular materials, is also able to predict the behavior of the RAP before and after binder extraction, with correlation values close to 0.9 .

Equation (13) details the relationship between $\gamma$, vertical modulus $\mathrm{E}_{\mathrm{v}}$ and horizontal modulus $\mathrm{E}_{\mathrm{h}}$. The parameter $\gamma$ reveals a highly anisotropic behavior for the RAP, with a ratio $E_{v} / E_{h}$ equal to 4.5, whereas for the RAP-BE this value is close to 2.7 .

$$
\frac{E_{v}}{E_{h}}=\frac{1}{\gamma^{2}} \#(13)
$$

Regarding the characteristic modulus $\mathrm{E}_{\mathrm{c}}$, the RAP has the highest value. According to the French Standard for Unbound Granular Materials (UGM) NF EN 13286-7 15 , this value corresponds to the performance of a good quality unbound granular material. After binder extraction, the material maintains a high modulus. In comparison, the characteristic modulus of the UGM is significantly lower than that of the RAP.

Page 14 of 26 
1

2

3

4

5

6

7

8

9

10

11

12

13

14

15

16

17

18

19

In terms of resilient behavior, the RAP before and after binder extraction present similar levels of strains and modulus. Consequently, the mastic does not seem to have a significant impact on the resilient behavior, at least for the tests at a frequency of $2 \mathrm{~Hz}$. In order to understand the role of the mastic, additional tests at different frequencies have been carried out and are presented below. 


\section{FIGURE 10}

Results for the constant cell pressure loadings at $2 \mathrm{~Hz}$ : (A) axial strains (B) radial strains (C) volumetric strains (D) deviatoric strains (E) resilient moduli

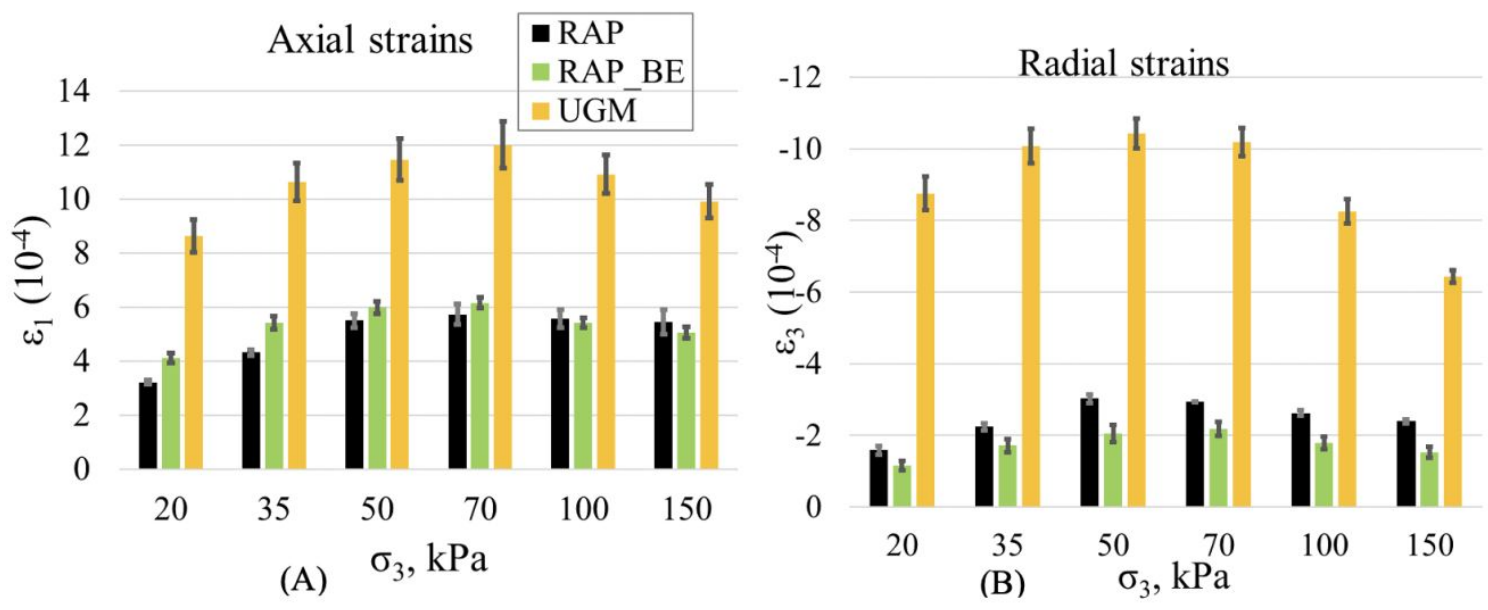

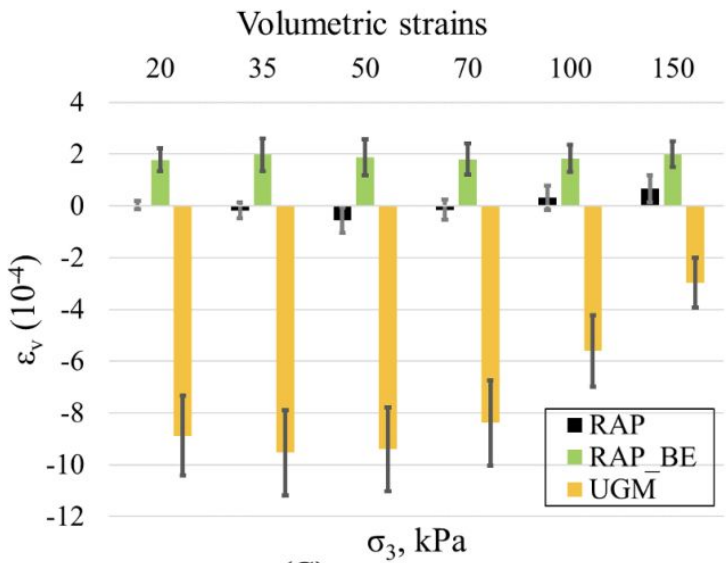

(C)

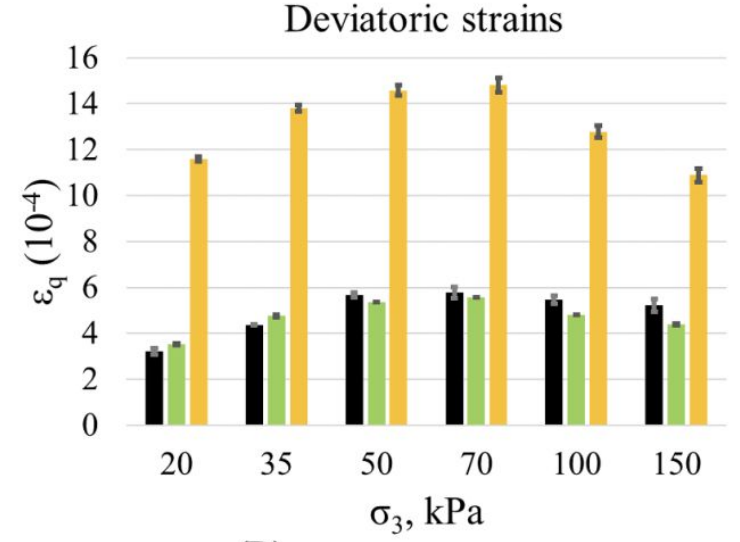

(D)

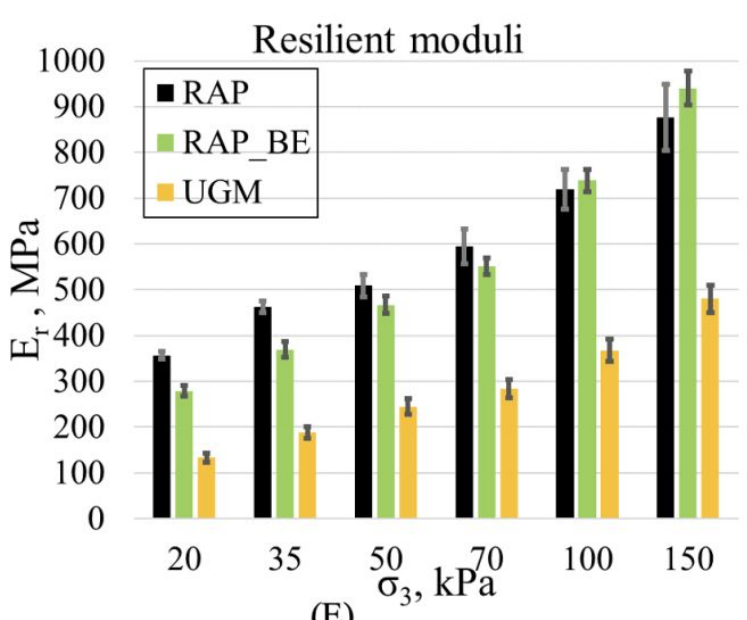

(E)

Page 16 of 26 


\section{FIGURE 11}

Results for the variable cell pressure loadings at $2 \mathrm{~Hz}$ : (A) axial strains (B) radial strains (C) volumetric strains (D) deviatoric strains (E) resilient moduli
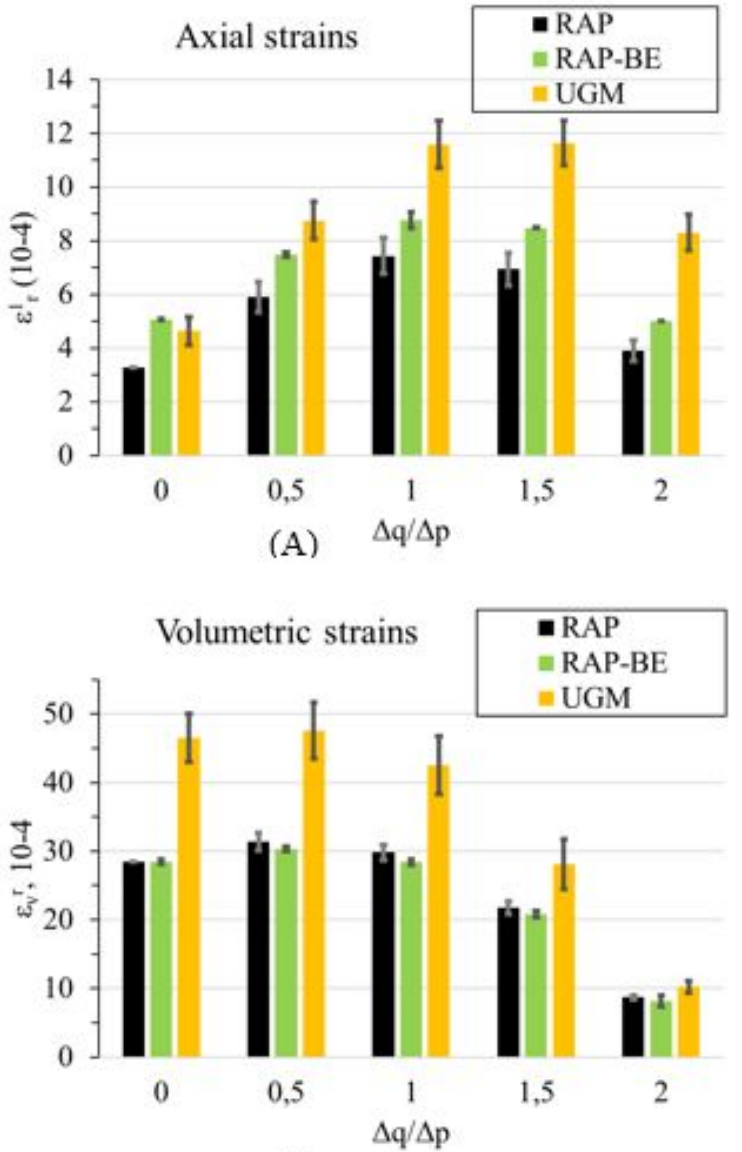

(C)

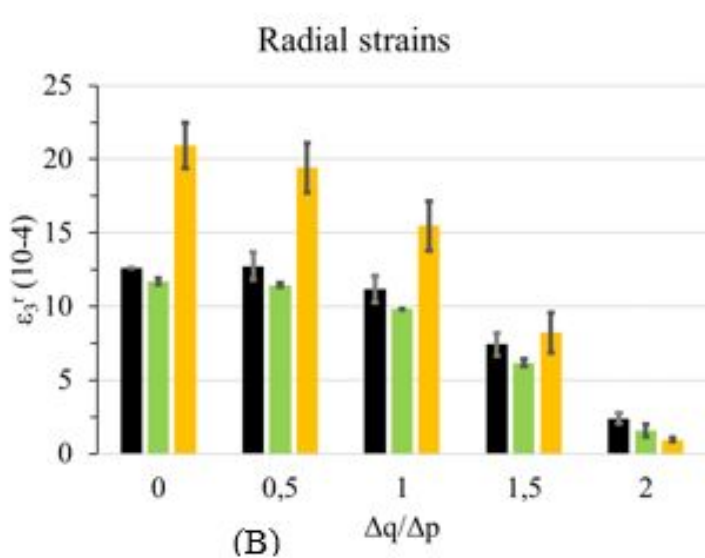

Deviatoric strains

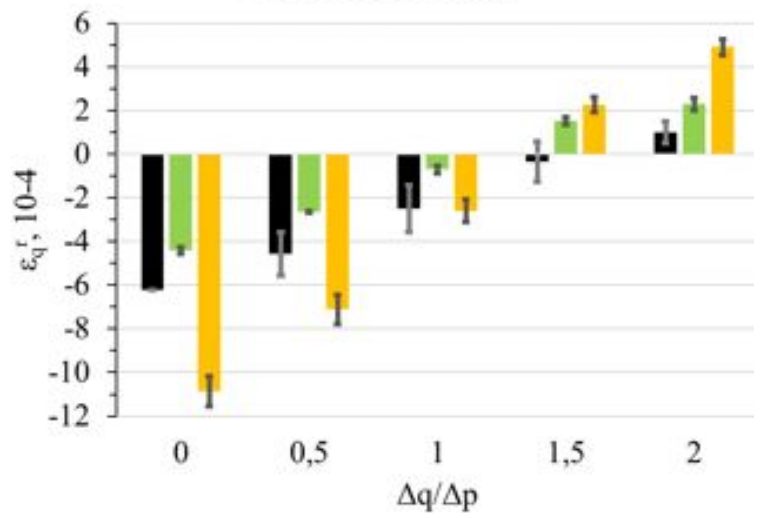

(D)

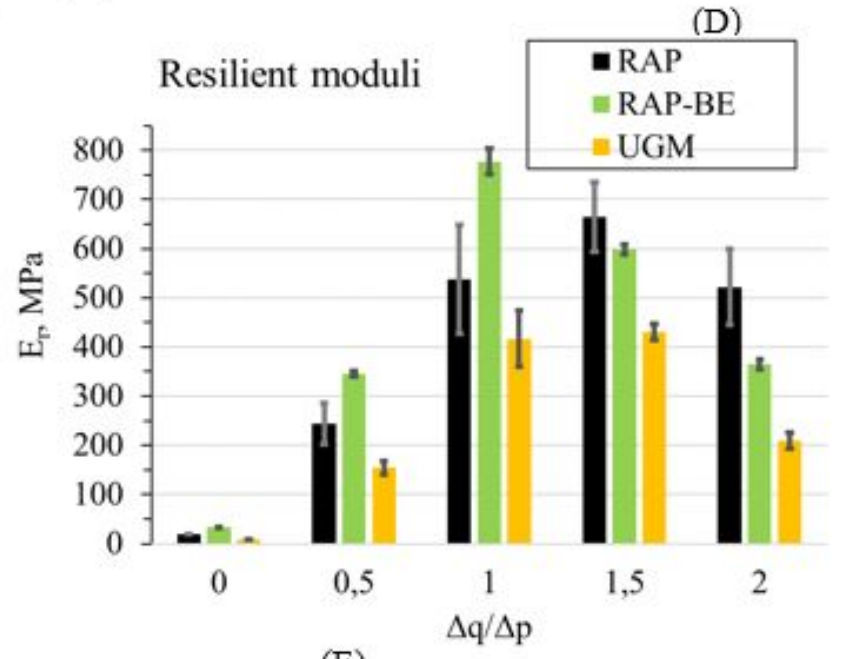

(E)

Page 17 of 26 


\section{FIGURE 12}

Boyce model calibration for the RAP at $2 \mathrm{~Hz}$

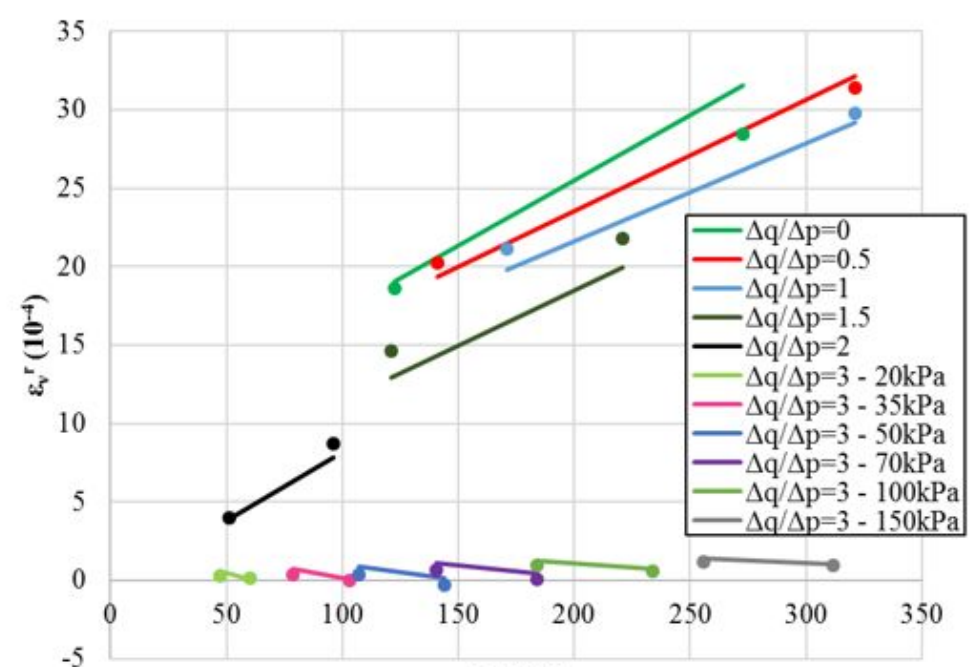

(A) $\quad \mathbf{p}[\mathrm{kPa}]$

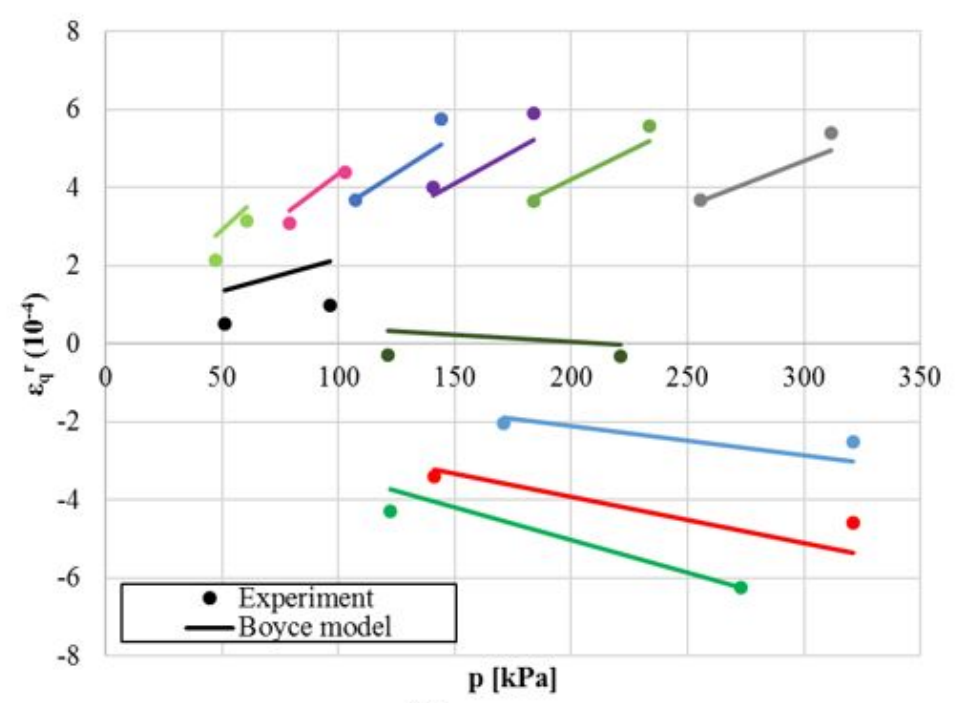

(B)

\section{TABLE 4}

Model parameters for calibrations at $2 \mathrm{~Hz}$

\begin{tabular}{lllllll}
\hline Material & $\mathrm{K}_{\mathrm{a}}, \mathrm{MPa}$ & $\mathrm{G}_{\mathrm{a}}, \mathrm{MPa}$ & $\mathrm{n}$ & $\gamma$ & $\mathrm{c}$ & $\mathrm{E}_{\mathrm{c}}, \mathrm{MPa}$ \\
\hline RAP & 20.73 & 52.18 & 0.34 & 0.47 & 0.88 & 519 \\
RAP-BE & 20.94 & 72.14 & 0.29 & 0.61 & 0.89 & 424 \\
UGM & 6.10 & 20.76 & 0.14 & 0.42 & 0.90 & 222 \\
\hline
\end{tabular}

Page 18 of 26 


\section{Influence of frequency}

Figures 13 and 14 show the evolution of the radial and axial strains of the RAP and RAP-BE during a resilient cycle at several frequencies between 0.1 and $10 \mathrm{~Hz}$.

First, the shape of cycles is similar for RAP before and after extraction. Both materials show a non-linear response typical of granular materials ${ }^{19}$. This phenomenon is characterized by a stressstrain curve with a hysteresis loop. The presence of bitumen does not change significantly the shape of the curves.

For the RAP, the test results indicate that the strains decrease when the frequency increases. Consequently, high frequency solicitations imply high modulus values. On the contrary, the influence of frequency is negligible for the RAP-BE. The maximum strains are almost the same for all frequencies, due to the absence of bitumen. In conclusion, the binder content of $4,4 \%$ in the RAP is sufficient to induce a viscous behavior, sensitive to frequency.

As shown on figure 15, the same effects can be observed for the volumetric and deviatoric strains, as well as for the characteristic modulus. Thus, the mastic coating has an influence on the behavior of the RAP and can allow a positive improvement of performance with time.

Page 19 of 26 


\section{FIGURE 13}

Evolution of (A) axial and (B) radial strains of the RAP during a resilient cycle at different frequencies for the stress path: $\Delta \mathrm{q} / \Delta \mathrm{p}=400 / 133=3, \sigma 3=100 \mathrm{kPa}$

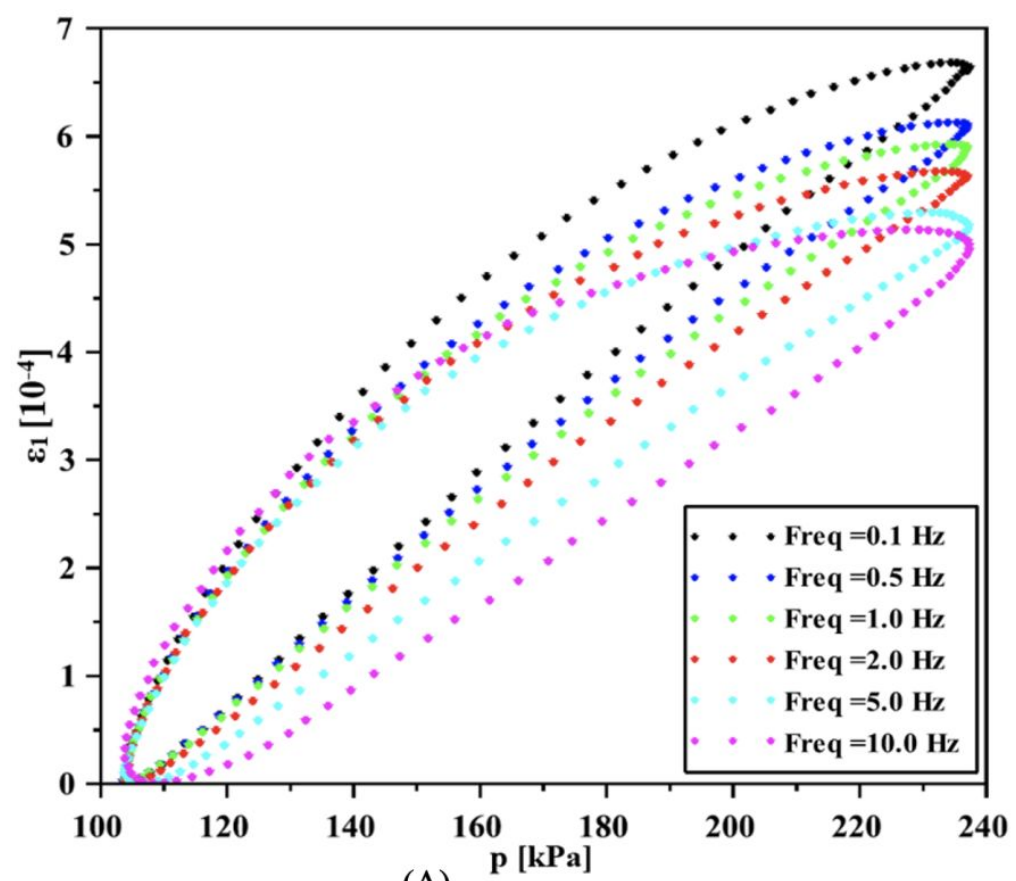

(A)

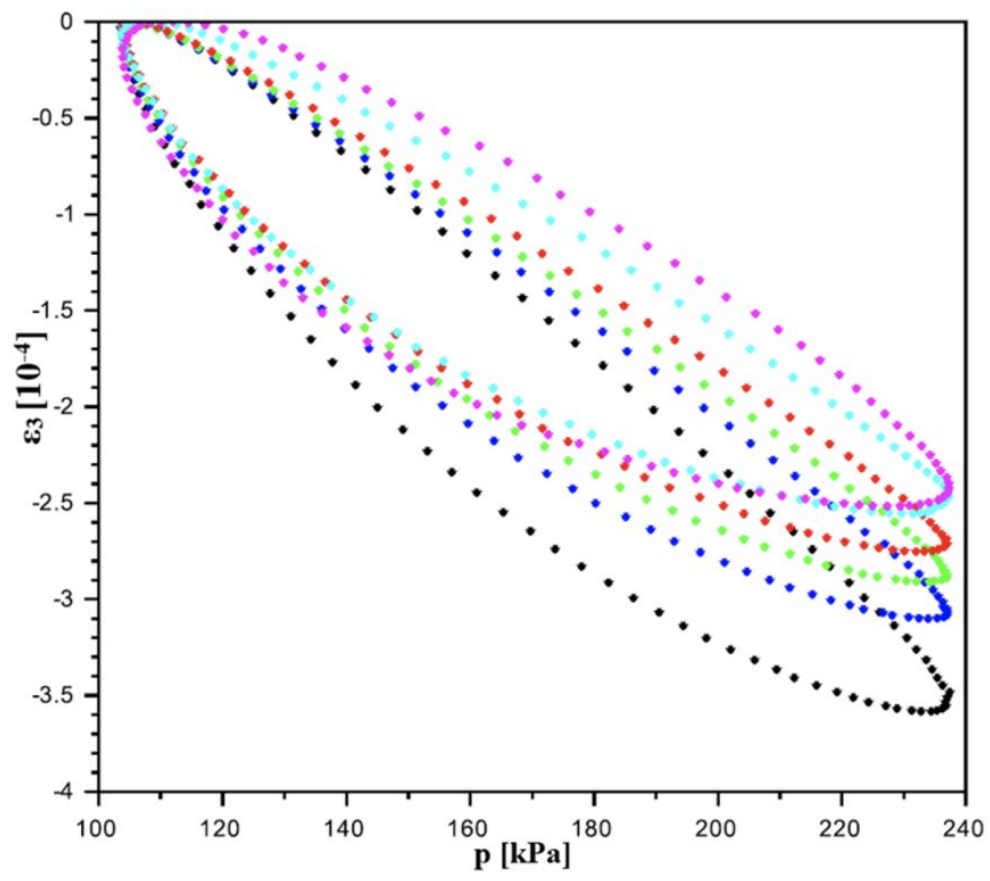

(B)

Page 20 of 26 


\section{FIGURE 14}

Evolution of (A) axial and (B) radial strains of the RAP-BE during a resilient cycle at different frequencies for the stress path: $\Delta \mathrm{q} / \Delta \mathrm{p}=400 / 133=3, \sigma 3=100 \mathrm{kPa}$
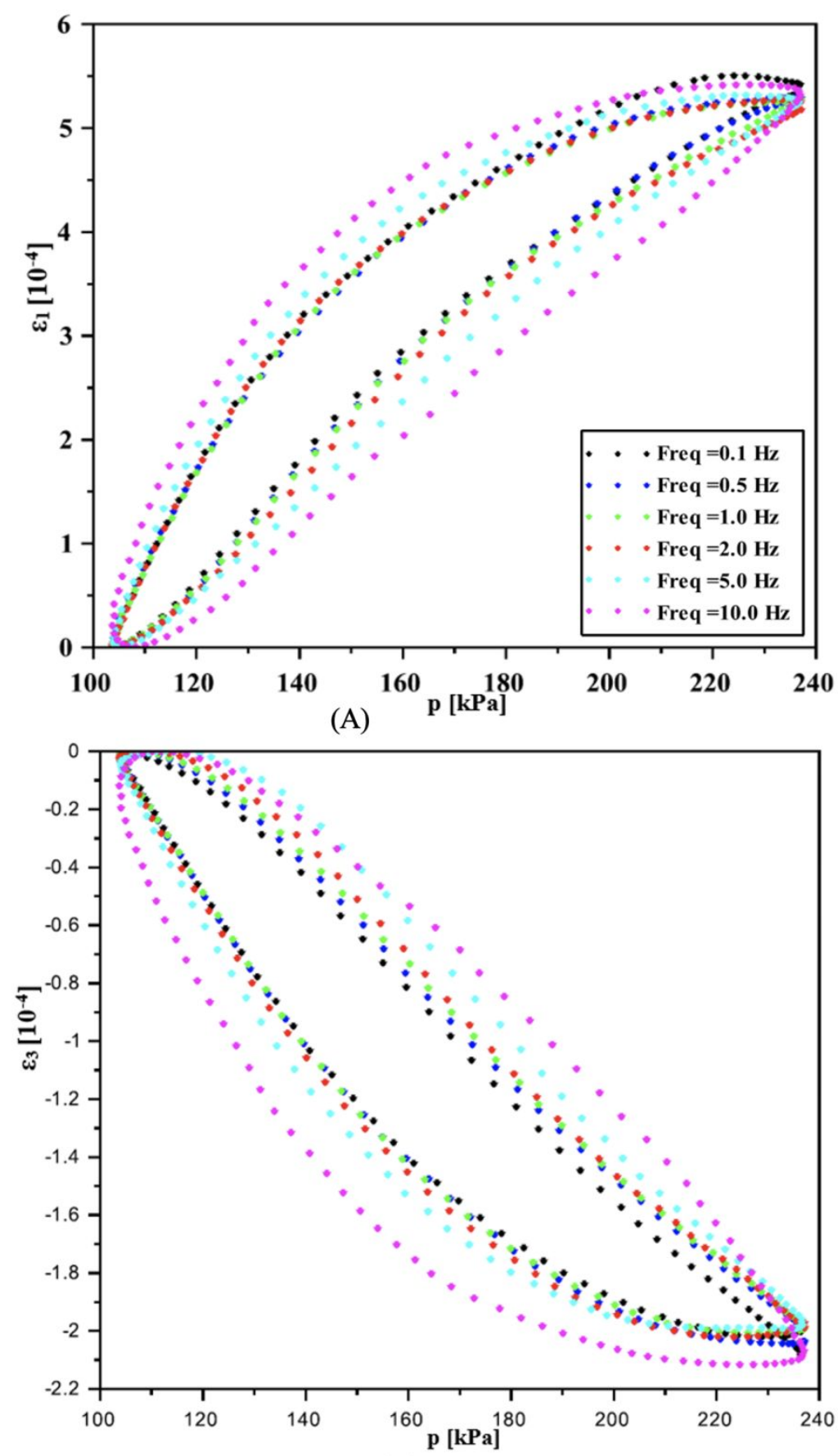

(B)

Page 21 of 26 


\section{FIGURE 15}

Results at several frequencies for the stress path $\Delta \mathrm{q} / \Delta \mathrm{p}=400 / 133=3, \sigma 3=100 \mathrm{kPa}$ : (A) volumetric strains (B) deviatoric strains (C) resilient moduli

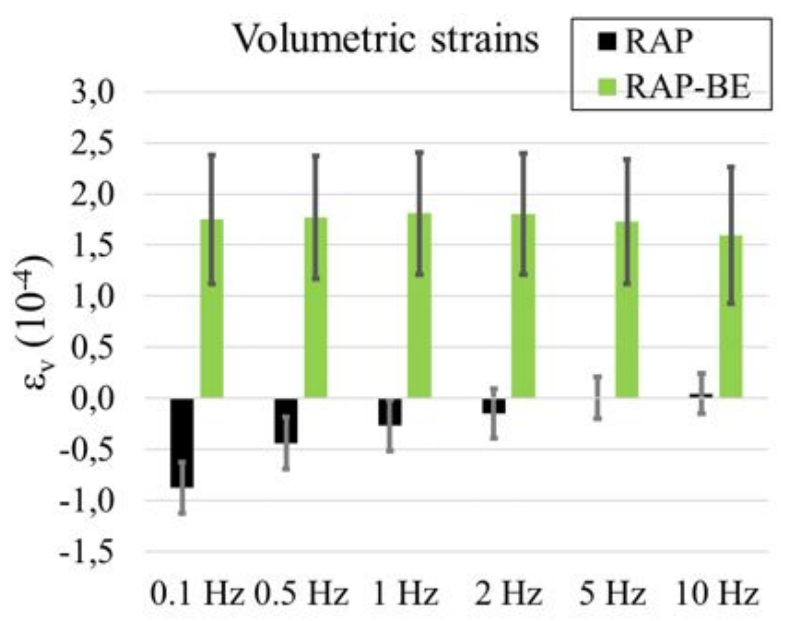

(A)

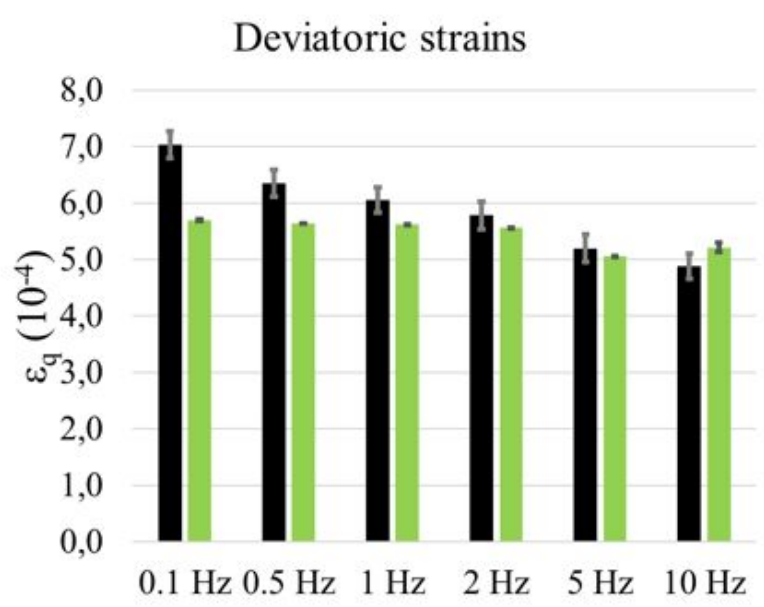

(B)

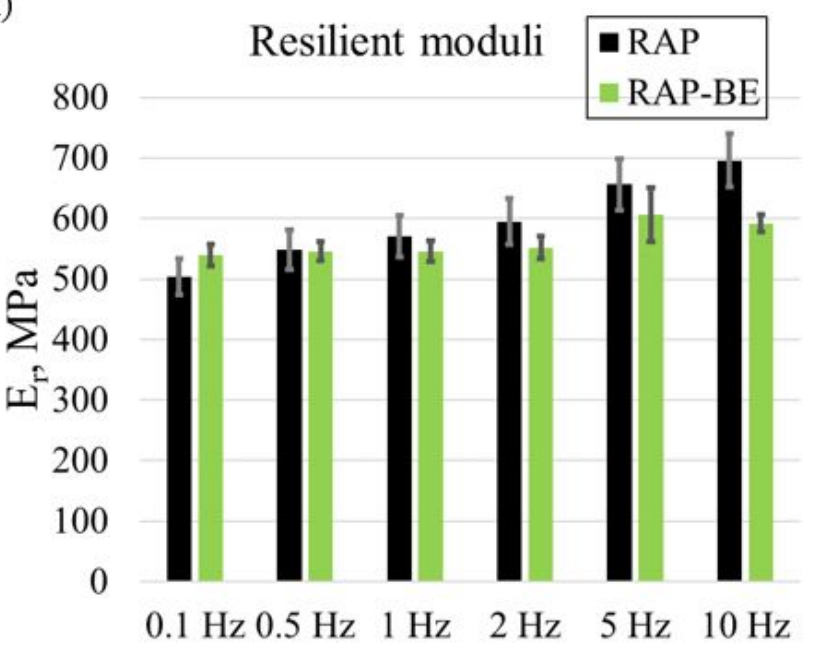

(C)

\section{Conclusions}

This paper presents some results of the study of a source of Reclaimed Asphalt Pavement (RAP), with a high Polycyclic Aromatic Hydrocarbons (PAH) content (298 mg/kg). The difference between an unbound granular material and the RAP is the presence of the binder (or mastic), which ensures a smooth contact between the rigid particles. This contact has consequences on the permanent and resilient behavior.

Page 22 of 26 
First, the conditioning phase reveals a clearly different permanent deformation behavior of the RAP before and after binder extraction. One possible explanation is the important fines content in the RAP-BE which has a beneficial effect on the rutting. The permanent strains of the RAP are high and outside specifications, according to the French Standard for Unbound Granular Materials (UGM) NF EN 13286-7 $7^{15}$. Nevertheless, the reclaimed material and the tested UGM presents a similar rutting resistance. In order to reduce the permanent strains, the in situ density can be increased.

Regarding the resilient behavior tests, the RAP specimens before and after binder extraction present similar results, and their performances are significantly higher than those of the UGM. The calibrations of the Boyce model, commonly used for granular materials, show that RAP presents a very similar behavior, and can be considered and utilized as an unbound granular material. However, the tests at different frequencies indicated some influence of the mastic on the behavior of the RAP. The behavior of the RAP was found to be sensitive to frequency (with an increase of stiffness when the frequency increases), whereas the impact of frequency on the RAPBE appeared negligible. Due to the mastic coating, bonding of the material could develop in the field, with time, and under the effect of post-compaction and lead to an increase of the mechanical properties with time.

In comparison with the tested UGM, the mechanical performances of the RAP are higher both regarding the rutting resistance and the characteristic elastic modulus, used for the pavement design. Consequently, these results confirm that the untreated RAP can be used in place of UGM, in base and subbase layers in low-traffic roads. This solution appears as an interesting alternative to disposal for contaminated RAP.

Page 23 of 26 


\section{ACKNOWLEDGEMENTS}

This work is part of the ORRAP (Optimal Recycling of Reclaimed Asphalts in low-traffic Pavements) project funded by ERDF - INTERREG V (3.1 ORRAP), which studies the cold recycling of reclaimed asphalts aggregates without binder addition.

\section{References}

1. J. Do Huh and J. Park, "A New Technology of Recycling $100 \%$ Reclaimed Asphalt

Pavements," Journal of Testing and Evaluation 37, no. 5 (2009): 479-482.

https://doi.org/10.1520/JTE000144

2. X. Li, M. O. Marasteanu, R. C. Williams, and T. Clyne, "Effect of reclaimed asphalt pavement (proportion and type) and binder grade on asphalt mixtures," Transportation Research Record 2051, no. 1 (January 2008): 90-97. https://doi.org/10.3141\%2F2051-11

3. S. Mangiafico, C. Sauzéat, H. Di Benedetto, S. Pouget, F. Olard, and L. Planque, "Complex modulus and fatigue performances of bituminous mixtures with reclaimed asphalt pavement and a recycling agent of vegetable origin," Road Materials and Pavement Design 18, no.2 (August 2016): 315-330. https://doi.org/10.1080/14680629.2016.1213509

4. G. Valdés, F. Pérez-Jiménez, R. Miró, A. Martínez, and R. Botella, "Experimental study of recycled asphalt mixtures with high percentages of reclaimed asphalt pavement (RAP)," Construction and Building Materials 25, no. 3 (September 2010): 1289-1297. https://doi.org/10.1016/j.conbuildmat.2010.09.016 5. M. Nazzal, S. Sargand, and A. Al-Rawashdeh, "Evaluation of Warm Mix Asphalt Mixtures Containing RAP Using Accelerated Loading Tests," Journal of Testing and Evaluation 39, no. 3 (2011): 305-312. https://doi.org/10.1520/JTE103158

Page 24 of 26 
6. L. Porot, and P. Eduard, "Laboratory evaluation of half-warm recycling with bio-based additive," Proceedings of Sixth Eurasphalt \& Eurobitume Congress (Prague, Czech Republic, June 1-3, 2016). dx.doi.org/10.14311/EE.2016.115

7. Z. Xie, N. Tran, A. Taylor, G. Julian, R. West, and J. Welch, "Evaluation of foamed warm mix asphalt with reclaimed asphalt pavement: field and laboratory experiments," Road Materials and Pavement Design 18, no.sup4 (October 2017): 328-352. https://doi.org/10.1080/14680629.2017.1389077

8. G. Betti, G. Airey, K. Jenkins, A. Marradi, and G. Tebaldi, “Active filler's effect on in situ performances of foam bitumen recycled mixtures," Road Materials and Pavement Design 18, no.2 (August 2016): 281-296. https://doi.org/10.1080/14680629.2016.1213486

9. F. V. Guatimosim, K. L. Vasconcelos, L. L. B. Bernucci, and K. J. Jenkins, "Laboratory and field evaluation of cold recycling mixture with foamed asphalt," Road Materials and Pavement Design 19, no. 2 (December 2016): 385-399. https://doi.org/10.1080/14680629.2016.1261726 10. C. Sangiorgi, P. Tataranni, A. Simone, V. Vignali, C. Lantieri, and G. Dondi, "A laboratory and field evaluation of Cold Recycling Mixture for base layer entirely made with Reclaimed Asphalt Pavement," Construction and Building Materials 138 (February 2017): 232-239. https://doi.org/10.1016/j.conbuildmat.2017.02.004

11. T. Jacobson, Atervinning av krossad asphalt som bär-och förstärkningslager. Del 2 Erfarenheter från fältstudier (Recycling of crushed asphalt in base course and subbase. Part 2 Field experiences), VTI notat 32-2002(2003) (Sweden: Swedish National Road and Transport Research Institute (VTI), February 2003).

12. Mélanges bitumineux - Spécifications pour le matériau-Partie 8 : Agrégats d'enrobés, NF EN 13108-8(2016) (La Plaine Saint-Denis, France: AFNOR, approved October 21, 2016). 
13. Graves non traitées - Spécifications, NF EN 13285 (2004) (La Plaine Saint-Denis, France: AFNOR, approved May 2004). https://www.afnor.org/

14. Mélanges bitumineux - Spécifications des matériaux - Partie 1 : Enrobés bitumineux, NF EN 13108-1 (2007) (La Plaine Saint-Denis, France: AFNOR, approved February 2007). 15. Mélanges avec ou sans liant hydraulique - Partie 7 : Essai triaxial sous charge cyclique pour mélanges sans liant hydraulique, NF EN 13286-7 (2004) (La Plaine Saint-Denis, France: AFNOR, approved July 2004). https://www.afnor.org/

16. P. Hornych, and A. El Abd, "Work package 5 Performance based specifications - Selection and evaluation of models for prediction of permanent deformations of unbound granular materials in road pavements," Report of SAMARIS project, February 2004, http://samaris.zag.si/docsys/documents/SAM_05_OT01v01_01.pdf 17. P. Jing, H. Nowamooz, and C. Chazallon, "Permanent deformation behaviour of a granular material used in low-traffic pavements," Road Materials and Pavement Design 19, no. 2 (December 2016): 289-314. https://doi.org/10.1080/14680629.2016.1259123

18. P. Jing, H. Nowamooz, and C. Chazallon, "Unsaturated mechanical behaviour of a granular material," Road Materials and Pavement Design 20, no. 6 (March 2018): 1429-1451. https://doi.org/10.1080/14680629.2018.1447506

19. J. R. Boyce, “A non-linear model for the elastic behaviour of granular materials under repeated loading," Proceedings of International Symposium on Soils under Cyclic and Transient Loading (Swansea, UK, January 7-11, 1980): 285-294

20. P. Hornych, A. Kazai, and J. M. Piau, "Study of the resilient behaviour of unbound granular materials," Proceedings of Fifth International Conference on the Bearing Capacity of Roads and Airfields (Trondheim, Norway, July 6-8, 1998): 1277-1287

Page 26 of 26 